\title{
Silicon nutrition counteracts salt-induced damage associated with changes in biochemical responses in apple
}

\author{
Servet Aras* (1), Hakan Keles (D), Ahmet Eşitken (D) \\ Yozgat Bozok University - Faculty of Agriculture - Department of Horticulture - Yozgat, Turkey
}

\begin{abstract}
Salt stress is an environmental challenge that adversely influences plant responses. Silicon (Si) nutrition plays critical roles in plant tolerance to salt stress. Apple (Malus domestica Borkh.), a salt sensitive fruit species, was used in the present experiment to investigate the influences of $\mathrm{Si}$ on salt stress as well as on alterations of biochemical responses. Apple cv Fuji grafted on M9 clonal rootstock was exposed to salt stress for 4 months with $35 \mathrm{mmol} \cdot \mathrm{L}^{-1} \mathrm{NaCl}$. CaSiO ${ }_{3}$ doses $\left(0.5,1\right.$ and $\left.2 \mathrm{mmol} \cdot \mathrm{L}^{-1}\right)$ were applied to the roots of the salt-stressed apple plants except control. Si application resulted in mitigation of salt stress in apple plants. The highest chlorophyll $a, b$ and $a+b$ were obtained from the $1 \mathrm{mmol} \cdot \mathrm{L}^{-1}$ Si treatment $\left(5.37,2.41\right.$ and $7.78 \mu \mathrm{g} \cdot \mathrm{g}^{-1} \mathrm{fw}$, respectively). Moreover, Si treatment had higher chlorophyll content compared to the control as well as salt exposed plants. Silicon applications led to a reduction in malondialdehyde (MDA) content even lower than control. The $0.5 \mathrm{mmol} \cdot \mathrm{L}^{-1} \mathrm{Si}$ treatment had the highest values of ascorbate peroxidase (APX) and phenolic content. The results show that $\mathrm{Si}$ nutrition plays important roles in apple salt tolerance via biochemical mechanisms and that it can be used in areas subject to salt stress for apple growing.
\end{abstract}

Key words: Malus domestica Borkh., plant behavior, rootstock, salinity.
Received:

Apr 19, 2019

Accepted:

Aug 8, 2019

Section Editor:

Hector Valenzuela

${ }^{*}$ Correspondence author: servet.aras@bozok.edu.tr

\section{INTRODUCTION}

Plants endure several environmental stressors and salt stress is one of the most common challenges limiting plant growth and development. Excessive fertilizer application with poor irrigation causes soil salinity, which may reach toxic levels for plants. Excessive salinity can cause oxidative stress and the formation of reactive oxygen species (ROS), thus resulting in lipid peroxidation, decrease in photosynthesis, and inhibition of enzymatic activities (Bressan et al. 1990). Temperate fruit trees, including apples, are salt-sensitive plants (Maas 1986). Apple cultivation under salt stress may result in a decline of fruit yield and quality. Salt stress impedes apple plant growth by decreasing water uptake, inhibition of photosynthesis, and by closing stomatal apertures (Yin et al. 2010; Fu et al. 2013).

One technique to promote plant tolerance against salt stress is utilization of some amendments (e.g., osmoprotectants, beneficial nutrients). In recent years, many experiments revealed that the application of silicon (Si) plays critical roles in plant tolerance to salt stress (Coskun et al. 2016; Aras and Eşitken 2018a). Silicon application has been observed to enhance tolerance of many stressors such as drought, and alkaline conditions (Abdel Latef and Tran 2016; Ma et al. 2016). Silicon is the second most abundant element on earth and plays an important role in stress tolerance, flowering and fruit quality (Dehghanipoodeh et al. 2016; Kim et al. 2017). Furthermore, Si is involved in cell wall reinforcement due to deposition of $\mathrm{Si}$ in epidermal cells to form a barrier (Trenholm et al. 2004; Romero-Aranda et al. 2006). Several experiments have documented the mitigation effects of Si application under salt stress on many plants. Conceição et al. (2019) examined the 
protective role of $\mathrm{Si}$ in sunflower when grown under salinity conditions. According to these authors, Si mitigated adverse effects of salt stress by inducing antioxidant systems and modulating nitrogen metabolism. Moreover, Haghighi and Pessarakli (2013) revealed that $\mathrm{Si}$ could increase plant tolerance against salt stress by protecting cell membrane stability in tomato. Hashemi et al. (2010) reported that Si nutrition mitigated salt damage in canola evidenced by declined lipid peroxidation and enhanced antioxidant enzymes.

Apple (Malus domestica Borkh.) is an important temperate zone fruit species. As a salt sensitive fruit species, it may suffer from salinity where excessive fertigation is practiced. Little information is available on Si mitigation of salt damage to woody plants at a biochemical level. In the current experiment, the biochemical effects of Si nutrition on mitigating damage from salt stress were studied in apple plants.

\section{MATERIAL AND METHODS Pot trials and experimental design}

The study was conducted in 2014 in a heated greenhouse of the Department of Horticulture at Selcuk University (lat $38^{\circ} 01^{\prime} 46^{\prime \prime} \mathrm{N}$, long $32^{\circ} 30^{\prime} 39^{\prime \prime} \mathrm{E}$ ) in Turkey and 1-year-old apple plants (Malus domestica Borkh.) cv. Fuji grafted onto M9 clonal rootstock were chosen for the experiment following a complete randomized plot design involving three replications, with three plants per replication. The plants were planted in March in $13 \mathrm{~L}$ pots with media consisting of soil, substrate and perlite $(1: 3: 1)$. The plants were placed in a semicontrolled greenhouse where temperatures fluctuated between $25-35^{\circ} \mathrm{C}$ and relative humidity range between $60-85 \%$ during the day. Up until the start of the experiment, all plants were irrigated with tap water and 1 month later (in April) saline-treatment plants were watered with $35 \mathrm{mmol} \cdot \mathrm{L}^{-1} \mathrm{NaCl}$ solution which is considered to be a moderate level of salinity for temperate fruit tree species (Akçay and Eşitken 2017; Aras and Eşitken 2018b). Two months after the salt stress was initiated, three different $\mathrm{CaSiO}_{3}$ doses $\left(0.5,1\right.$ and $\left.2 \mathrm{mmol} \cdot \mathrm{L}^{-1}\right)$ were applied twice a month (in June and July) to the plant rhizosphere as a solution, except the controls. Plants were watered three times a week and fertilized once a week with Hoagland's nutrient solution (Hoagland and Arnon 1950). Excess solution was allowed to drain from the pot. Control and salt-treated control plants were not treated with $\mathrm{CaSiO}_{3}$, salt treated plants were watered with $\mathrm{NaCl}$ solution compared to the tap-water treated control. After 4 months of salinity treatments (in August), several biochemical properties were evaluated.

Matured leaves were used for protein content determination. The leaf segments were ground in cold phosphate buffer (pH 6.5) and then filtered. The filtrate was centrifuged at $4000 \mathrm{~g}$ for $20 \mathrm{~min}$ at $4{ }^{\circ} \mathrm{C}$. The supernatant was decanted and then the Bradford Protein Kit was added. The mixture was vigorously shaken with vortex. The sample absorbance was read at $595 \mathrm{~nm}$. The protein levels were estimated by the method of Bradford (1976) using bovine serum albumin as standard and expressed at mg protein $\mathrm{g}^{-1}$ fresh weight ( $\mathrm{fw}$ ).

The proline content was estimated by the method of Bates et al. (1973). The plant material was homogenized in 3\% aqueous sulfosalicylic acid and the homogenate was centrifuged at 10,000 rpm. The supernatant was used for estimation of the proline content. The reaction mixture consisted of $2 \mathrm{ml}$ supernatant, $2 \mathrm{ml}$ acid ninhydrin and $2 \mathrm{ml}$ of glacial acetic acid, which was boiled at $100{ }^{\circ} \mathrm{C}$ for $1 \mathrm{~h}$. After termination of the reaction in ice bath, the reaction mixture was extracted with $4 \mathrm{ml}$ of toluene and the absorbance was read at $520 \mathrm{~nm}$.

For the determination of chlorophyll $(\mathrm{a}, \mathrm{b}$ and $\mathrm{a}+\mathrm{b})$ content, fine powder $(0.1 \mathrm{~g})$ of the leaves was homogenized in $10 \mathrm{~mL}$ of $80 \%$ acetone, and then centrifuged at 12,000 $\mathrm{g}$ for $10 \mathrm{~min}$. The chlorophyll $(\mathrm{a}, \mathrm{b}$, and $\mathrm{a}+\mathrm{b}$ ) content was spectrophotometrically determined by measuring absorbance at 663 and at $646 \mathrm{~nm}$. The chlorophyll $(\mathrm{a}, \mathrm{b}$ and $\mathrm{a}+\mathrm{b})$ content was calculated using the equations of Porra et al. (1989), as follows: (1) chlorophyll a $\left(\mu \mathrm{g} \cdot \mathrm{mL}^{-1}\right)=12.25 \mathrm{~A} 663-2.55 \mathrm{~A} 646$; (2) chlorophyll b $\left(\mu \mathrm{g} \cdot \mathrm{mL}^{-1}\right)=20.31 \mathrm{~A} 646-4.91 \mathrm{~A} 663$; and $(3)$ chlorophyll $\mathrm{a}+\mathrm{b}\left(\mu \mathrm{g} \cdot \mathrm{mL}^{-1}\right)=17.76 \mathrm{~A} 646+7.34 \mathrm{~A} 663$.

The chlorophyll stability index (CSI) was calculated as follows (Sairam et al. 1997): CSI = (total chlorophyll under stress/total chlorophyll under control) $\times 100$. 
For the quantification of total phenols, methanol was used for extraction. Total phenolic content was assayed by A765 with Folin-Cocalteau reagent (Singleton and Rossi 1965). The results were expressed as $\mu$ g of p-hydroxycinnamic acid ( $g$ fresh weight).

The lipid peroxidation was determined by estimating the malondialdehyde (MDA) content in $1 \mathrm{~g}$ leaf fresh weight according to Madhava Rao and Sresty (2000). MDA is a product of lipid peroxidation by the thiobarbituric acid reaction. The concentration of MDA was calculated from the absorbance at $532 \mathrm{~nm}$ by using an extinction coefficient of $155 \mathrm{mmol} \cdot \mathrm{L}^{-1} \cdot \mathrm{cm}^{-1}$.

The ascorbate peroxidase (APX) activity was estimated according to the method of Nakano and Asada (1981). The enzyme activity was determined by the decline in absorbance of ascorbate at $290 \mathrm{~nm}$. The reaction mixture consisted of enzymatic extract, $50 \mathrm{mmol} \cdot \mathrm{L}^{-1}$ sodium phosphate buffer, $\mathrm{pH}$ 7, $0.5 \mathrm{mmol} \cdot \mathrm{L}^{-1}$ ascorbate, $0.5 \mathrm{mmol} \cdot \mathrm{L}^{-1} \mathrm{H}_{2} \mathrm{O}_{2}$ and $0.1 \mathrm{mmol} \cdot \mathrm{L}^{-1}$ EDTA, in a $0.3 \mathrm{ml}$ final volume. The reaction started after the hydrogen peroxide addition. The molar extinction coefficient $2.8 \mathrm{mmol} \cdot \mathrm{L}^{-1} \cdot \mathrm{cm}^{-1}$ was used to calculate APX activity. Enzyme activity was expressed at unit's. $\mathrm{mg}^{-1}$ protein. One unit of enzyme was the amount necessary to decompose $1 \mu \mathrm{mol}$ of the substrate per minute at $25^{\circ} \mathrm{C}$.

Statistical analyses were performed with the statistical software package SPSS, version 20.0. The means were compared by the Duncan's multiple-comparisons test at $5 \%$.

\section{RESULTS}

Salt stress and Si applications affected several biochemical responses in apple plants. There was a considerable increase in the chlorophyll content. The highest chlorophyll a, b and $\mathrm{a}+\mathrm{b}$ were obtained from the $1 \mathrm{mmol} \cdot \mathrm{L}^{-1} \mathrm{Si}$ treatment (Table 1) increasing chlorophyll contents by 68, 32 and 55\%, respectively. In addition to the chlorophyll content, $1 \mathrm{mmol} \cdot \mathrm{L}^{-1} \mathrm{Si}$ increased the chlorophyll stability index $\mathrm{a}, \mathrm{b}$ and $\mathrm{a}+\mathrm{b}$ by 75,36 and $60 \%$, respectively compared to the salt only treatment (Table 2).

Significant increases in protein and proline content were obtained with the salt treatment compared to the water-only control (Table 3). The 0.5 and $1 \mathrm{mmol} \cdot \mathrm{L}^{-1} \mathrm{Si}$ applications had lower protein and proline contents compared to saline-treated plant. Furthermore, $2 \mathrm{mmol} \cdot \mathrm{L}^{-1} \mathrm{Si}$ possessed lower proline content compared to saline-treated plant. Si applications led to a reduction in MDA content even lower than the control, while the salt treatment significantly increased the MDA content by $24 \%$ compared to the control (Table 3 ). The $0.5 \mathrm{mmol} \mathrm{L}^{-1}$ Si treatment had the highest values of APX and phenolic content among all treatments (Table 3 ).

Table 1. Effect of $\mathrm{CaSiO}_{3}$ on chlorophyll content on apple plants exposed to moderate levels of salinity $\left(35 \mathrm{mmol} \cdot \mathrm{L}^{-1} \mathrm{NaCl}\right)$.

\begin{tabular}{cccr}
\hline Treatments & $\mathrm{Chla}\left(\mu \mathrm{g} \cdot \mathrm{g}^{-1} \mathrm{fw}\right)$ & $\mathrm{Chl} \mathrm{b}\left(\mu \mathrm{g} \cdot \mathrm{g}^{-1} \mathrm{fw}\right)$ & $\mathrm{Chla}+\mathrm{b}\left(\mu \mathrm{g} \cdot \mathrm{g}^{-1} \mathrm{fw}\right)$ \\
\hline Control & $3.20 \mathrm{~d}$ & $1.82 \mathrm{c}$ & $5.03 \mathrm{~d}$ \\
\hline $\mathrm{NaCl}$ & $3.07 \mathrm{~d}$ & $1.77 \mathrm{c}$ & $4.85 \mathrm{~d}$ \\
\hline $0.5 \mathrm{mmol} \cdot \mathrm{L}^{-1} \mathrm{CaSiO}_{3}+\mathrm{NaCl}$ & $3.90 \mathrm{c}$ & $1.92 \mathrm{c}$ & $5.83 \mathrm{c}$ \\
\hline $1 \mathrm{mmol} \cdot \mathrm{L}^{-1} \mathrm{CaSiO}_{3}+\mathrm{NaCl}$ & $5.37 \mathrm{a}$ & $2.41 \mathrm{a}$ & $7.78 \mathrm{a}$ \\
\hline $2 \mathrm{mmol} \cdot \mathrm{L}^{-1} \mathrm{CaSiO}_{3}+\mathrm{NaCl}$ & $4.93 \mathrm{~b}$ & $2.15 \mathrm{~b}$ & $7.09 \mathrm{~b}$ \\
\hline
\end{tabular}

Means separation within columns by Duncan's multiple range test, $p<0.05$.

Table 2. Effect of $\mathrm{CaSiO}_{3}$ on chlorophyll stability index (CSI) a, b and a + b on apple plants exposed to moderate levels of salinity (35 mmol. $\mathrm{L}^{-1} \mathrm{NaCl}$ ).

\begin{tabular}{cccc}
\hline Treatments & Chl a CSI & Chl b CSI & $98.70 \mathrm{c}$ \\
\hline $\mathrm{NaCl}$ & $96.14 \mathrm{~d}$ & $107.03 \mathrm{c}$ & $115.90 \mathrm{c}$ \\
\hline $0.5 \mathrm{mmol} \cdot \mathrm{L}^{-1} \mathrm{CaSiO}_{3}+\mathrm{NaCl}$ & $121.97 \mathrm{c}$ & $133.88 \mathrm{a}$ \\
\hline $1 \mathrm{mmol} \cdot \mathrm{L}^{-1} \mathrm{CaSiO}_{3}+\mathrm{NaCl}$ & $167.91 \mathrm{a}$ & $119.81 \mathrm{~b}$ & $154.73 \mathrm{a}$ \\
\hline $2 \mathrm{mmol} \cdot \mathrm{L}^{-1} \mathrm{CaSiO}_{3}+\mathrm{NaCl}$ & $154.16 \mathrm{~b}$ & $\mathrm{~b}$ \\
\hline
\end{tabular}

Means separation within columns by Duncan's multiple range test, $p<0.05$. 
Table 3. Effect of $\mathrm{CaSiO}_{3}$ on protein, proline, malondialdehyde (MDA), ascorbate peroxidase (APX) and phenolic contents on apple plants exposed to moderate levels of salinity $\left(35 \mathrm{mmol} \mathrm{L}^{-1} \mathrm{NaCl}\right)$.

\begin{tabular}{|c|c|c|c|c|c|}
\hline Treatments & $\begin{array}{l}\text { Protein } \\
\left(\mu \mathrm{g} \cdot \mathrm{g}^{-1} \mathrm{fw}\right)\end{array}$ & $\begin{array}{c}\text { Proline } \\
\left(\mu \mathrm{mol} \mathrm{g}^{-1} \mathrm{fw}\right)\end{array}$ & $\begin{array}{c}\text { MDA } \\
\left(\mu \mathrm{mol} \mathrm{g}^{-1} \mathrm{fw}\right)\end{array}$ & $\begin{array}{c}\text { APX } \\
\left(\mu \mathrm{mol} \mathrm{g}^{-1} \mathrm{fw}_{\mathrm{min}^{-1}}\right)\end{array}$ & $\begin{array}{c}\text { Phenolic } \\
\left(\mu \mathrm{g} \text { GAE } 100 \mathrm{~g}^{-1} \mathrm{fw}\right)\end{array}$ \\
\hline Control & $0.0110 \mathrm{~b}$ & 0.0120 NS & $0.0021 \mathrm{ab}$ & $226.66 \mathrm{ab}$ & $0.091 \mathrm{bc}$ \\
\hline $\mathrm{NaCl}$ & $0.0145 \mathrm{ab}$ & 0.0156 & $0.0026 a$ & $281.66 \mathrm{a}$ & $0.105 b$ \\
\hline $0.5 \mathrm{mmol} \cdot \mathrm{L}^{-1} \mathrm{CaSiO}_{3}+\mathrm{NaCl}$ & $0.0144 a b$ & 0.0130 & $0.0018 b$ & $145.00 \mathrm{c}$ & $0.085 c$ \\
\hline $1 \mathrm{mmol} \cdot \mathrm{L}^{-1} \mathrm{CaSiO}_{3}+\mathrm{NaCl}$ & $0.0135 b$ & 0.0146 & $0.0020 \mathrm{ab}$ & $193.33 \mathrm{bc}$ & $0.095 \mathrm{bc}$ \\
\hline $2 \mathrm{mmol} \cdot \mathrm{L}^{-1} \mathrm{CaSiO}_{3}+\mathrm{NaCl}$ & $0.0175 a$ & 0.0113 & $0.0018 \mathrm{~b}$ & $226.66 \mathrm{ab}$ & $0.124 a$ \\
\hline
\end{tabular}

Means separation within columns by Duncan's multiple range test, $p<0.05$. NS = nonsignificant.

\section{DISCUSSION}

Salt stress influences many biochemical responses in plants. In the current experiment, the protective effects of Si application in apple plant under salinity conditions were investigated. This work revealed that supplemental Si nutrition could effectively increase the tolerance of young apple plants to salt stress. Leaf-tip necrosis is utilized as an indicator of $\mathrm{NaCl}$ toxicity and remarkable necrosis in salt-treated control plants was observed. The Si treated plants showed less necrosis compared to the salt-treated control. Visual symptoms as leaf scorch were observed one month after the onset of saline stress. In the short term (for one month), there was no any symptom as reported in previous experiments (Aras and Eşitken 2018b).

Chlorophyll biosynthesis is a conspicuous process that is necessary for photosynthesis. Chlorophyll is made from 5-aminolaevulinic acid (ALA) (Beale 1999) that was reported to decrease in salt stressed plant leaves (Santos 2004; Tavallali et al. 2008). Moreover, the decrease in chlorophyll content may be due to an increase in chlorophyll degradation and/or decrease in mineral acquisition needed for chlorophyll synthesis (El-Desouky and Atawia 1998). In the current study, salinity decreased chlorophyll content in apple plants. The highest contents of chlorophyll $\mathrm{a}, \mathrm{b}$ and $\mathrm{a}+\mathrm{b}$ were obtained with the $1 \mathrm{mmol} \cdot \mathrm{L}^{-1} \mathrm{Si}$ treatment. Furthermore, the Si treatment considerably increased chlorophyll content in apple leaves, compared to the control as well as the salt treated plants.

Magnesium (Mg) is the key element of chlorophyll (Chen et al. 2017) and iron (Fe) is used for chlorophyll formation (Miller et al. 1984). Silicon may induce internal Fe and Mg transport, leading to the synthesis of chlorophyll. Similarly, as with the chlorophyll content, the Si treatment increased the CSI. Chlorophyll stability index can be used as a rapid method to estimate resistance to stresses (Rahbarian et al. 2011; Aras et al. 2019). The $1 \mathrm{mmol} \cdot \mathrm{L}^{-1} \mathrm{Si}$ treatment increased CSI a, b and $\mathrm{a}+\mathrm{b}$ compared to salt treated plants. These results are in agreement with Rahbarian's et al. (2011) findings who observed a decrease in CSI of chickpea genotypes under drought stress.

Salt damage in plants may result from the production of ROS. Reactive oxygen species formation may cause cellular damage, and was reflected in terms of the increased MDA content in salt-exposed leaves, in accordance with the results obtained by Zhang et al. (2018) and Liu et al (2014). Exogenously applied Si had a likely protective effect on salt induced membrane damage. Under salinity, $\mathrm{Si}$ is deposited on cell walls and such deposition strengthens the cell membranes (Liang et al. 2005; Zhang et al. 2018). Therefore, Si addition may have reinforced membranes of plant cells and prevented ion leakage from membranes as evinced by the observed decrease in lipid peroxidation. Silicon thus likely had antisalt stress effects due to its membrane stabilizing property. Moreover, Si may have provided better cell membranes against salinity, as $\mathrm{Si}$ competes with $\mathrm{Na}^{+}$for membrane binding spots. A protective effect of $\mathrm{Si}$ on relative membrane injury under salt stress has been previously reported (Tuna et al. 2008; Hashemi et al. 2010). Silicon itself acts as an antioxidant and scavenges ROS, resulting in reduced MDA content.

Accumulation of protein and proline is a common physiological response against salt stress (Yoon et al. 2005; Khadri et al. 2006). Conversely, a decrease in protein and proline content in response to Si treatment, which was observed in our experiment, may indicate low salt stress damage. In a study by Lee et al. (2010), Si treatment decreased proline content in soybean under salt stress conditions. Similar results with protein and proline content were obtained with respect to phenolic 
content and APX activity in the present study. Decreases in phenolic content and APX enzyme activity were detected in apple plants treated with Si under salt stress. Although phenolics and APX activity elevate as a defense mechanism, increased levels of phenolics and APX activity may demonstrate the level of stress damage, thus, it can be stated that low contents of phenolics and APX activity likely reflect less stress damage. Thus, this work postulate that Si treatment has beneficial influences by acting as an antioxidant and functioning in plant defense against salt stress. In a previous work with canola, it was proposed that a decrease in plant growth may have resulted from the increased phenolic content in plants exposed to salinity (Hashemi et al. 2010).

\section{CONCLUSION}

Taken together, the results of the current experiment attribute the protective role of Si in salt stress alleviation to its improvement of antioxidant activity, protection of cell membranes and enhancing chlorophyll content thus photosynthesis. The results suggest that Si nutrition can improve the establishment of apple cultivation in areas subject to salt stress. This work considers that the Si $1 \mathrm{mmol} \cdot \mathrm{L}^{-1}$ level was more effective that the other Si levels, the reason may be due to protecting chlorophyll and showing less protein content that is related with indicating less salt stress damage. The results indicate that Si utilization in the greenhouse on plants exposed to salinity also reflect the potential use of Si under field conditions.

\section{AUTHORS' CONTRIBUTION}

Conceptualization, Aras, S. and Eşitken, A.; Methodology, Aras, S. and Keles, H.; Investigation, Aras, S. and Eşitken, A.; Writing - Original Draft, Aras, S.; Writing - Review and Editing, Aras, S.; Resources, Aras, S., Keles, H. and Eşitken, A.

\section{REFERENCES}

Abdel Latef, A. A. and Tran, L.-S. P. (2016). Impacts of priming with silicon on the growth and tolerance of maize plants to alkaline stress. Frontiers in Plant Science, 7, 243. https://doi.org/10.3389/fpls.2016.00243

Akçay, D. and Eşitken, A. (2017). MM106 anacı ve üzerine aşılı Golden Delicious elma çeşidine tuz stresinin etkileri. Selçuk Tarım Bilimleri Dergisi, 3, 228-232.

Aras, S. and Eşitken, A. (2018a). Effects of silicon to salt stress on strawberry plant. Harran Tarım ve Gıda Bilimleri Dergisi, $22,478-483$. https://doi.org/10.29050/harranziraat.436131

Aras, S. and Eşitken, A. (2018b). Physiological responses of cherry rootstocks to short term salinity. Erwerbs-Obstbau, $60,161-164$. https://doi.org/10.1007/s10341-017-0350-x

Aras, S., Keles, H. and Eşitken, A. (2019). SNP mitigates malignant salt effects on apple plants. Erwerbs-Obstbau, 1-9. https://doi. org/10.1007/s10341-019-00445-1

Bates, L. S., Waldren, R. P. and Teare, I. D. (1973). Rapid determination of free proline for water-stress studies. Plant and Soil, 39, 205207. https://doi.org/10.1007/BF00018060

Beale, S. I. (1999). Enzymes of chlorophyll biosynthesis. Photosynthesis Research, 60, 43-73. https://doi.org/10.1023/A:1006297731456

Bradford, M. M. (1976). A rapid and sensitive method for the quantitation of microgram quantities of protein utilizing the principle of protein-dye binding. Analytical Biochemistry, 72, 248-254. https://doi.org/10.1016/0003-2697(76)90527-3 
Bressan, R. A., Nelson, D. E., Iraki, N. M., LaRosa, P. C., Singh, N. K., Hasegawa, P. M. and Carpita, N. C. (1990). Reduced cell expansion and changes in cell walls of plant cells adapted to NaCl. In Katterman, F. (Ed.). Environmental injury to plants, 137-171. San Diego: Academic Press.

Chen, J., Li, Y., Wen, S., Rosanoff, A., Yang, G. and Sun, X. (2017). Magnesium fertilizer-induced increase of symbiotic microorganisms improves forage growth and quality. Journal of Agricultural and Food Chemistry, 65, 3253-3258. https://doi.org/10.1021/acs.jafc.6b05764

Conceição, S. S., Oliveira Neto, C. F. D., Marques, E. C., Barbosa, A. V. C., Galvão, J. R., Oliveira, T. B. D., Okumura, R. S., Martins, J. T. S., Costa, T. C. and Gomes-Filho, E. (2019). Silicon modulates the activity of antioxidant enzymes and nitrogen compounds in sunflower plants under salt stress. Archives of Agronomy and Soil Science, 65, 1237-1247, https://doi.org/10.1080/03650340.2018.1562272

Coskun, D., Britto, D. T., Huynh, W. Q. and Kronzucker, H. J. (2016). The role of silicon in higher plants under salinity and drought stress. Frontiers in Plant Science, 7, 1-4. https://doi.org/10.3389/fpls.2016.01072

Dehghanipoodeh, S., Ghobadi, C., Baninasab, B., Gheysari, M. and Bidabadi, S. S. (2016). Effects of potassium silicate and nanosilica on quantitative and qualitative characteristics of a commercial strawberry (fragaria $\times$ ananassa cv. 'camarosa'). Journal of Plant Nutrition, 39, 502-507. https://doi.org/10.1080/01904167.2015.1086789

El-Desouky, S. A. and Atawia, A. A. R. (1998). Growth performance of some citrus rootstocks under saline conditions. Alexandria Journal of Agricultural Research, 43, 231-254.

Fu, M., Li, C. and Ma, F. (2013). Physiological responses and tolerance to NaCl stress in different biotypes of Malus prunifolia. Euphytica, 189, 101-109. https://doi.org/0.1007/s10681-012-0721-1

Haghighi, M. and Pessarakli, M. (2013). Influence of silicon and nano-silicon on salinity tolerance of cherry tomatoes (Solanum lycopersicum L.) at early growth stage. Scientia Horticulturae, 161, 111-117. https://doi.org/10.1016/j.scienta.2013.06.034

Hashemi, A., Abdolzadeh, A. and Sadeghipour, H. R. (2010). Beneficial effects of silicon nutrition in alleviating salinity stress in hydroponically grown canola, Brassica napus L., plants. Soil Science and Plant Nutrition, 56, 244-253. https://doi.org/10.1111/j.1747-0765.2009.00443.x

Hoagland, D. R. and Arnon, D. I. (1950). The water-culture method for growing plants without soil. Berkeley: California Agricultural Experiment Station.

Khadri, M., Tejera N. A.and Lluch, C. (2006). Alleviation of salt stress in common bean (Phaseolus vulgaris) by exogenous abscisic acid supply. Journal of Plant Growth Regulation, 25, 110-119. https://doi.org/10.1007/s00344-005-0004-3

Kim, Y. H., Khan, A. L., Waqas, M. and Lee, I. J. (2017). Silicon regulates antioxidant activities of crop plants under abiotic-induced oxidative stress: a review. Frontiers in Plant Science, 8, 510. https://doi.org/10.3389/fpls.2017.00510

Lee, S. K., Sohn, E. Y., Hamayun, M., Yoon, J. Y. and Lee, I. J. (2010). Effect of silicon on growth and salinity stress of soybean plant grown under hydroponic system. Agroforestry Systems, 80, 333-340. https://doi.org/10.1007/s10457-010-9299-6

Liang, Y., Zhang, W., Chen, Q. and Ding, R. (2005). Effects of silicon on $\mathrm{H}^{+}$-ATPase and $\mathrm{H}^{+}$-PPase activity, fatty acid composition and fluidity of tonoplast vesicles from roots of salt-stressed barley (Hordeum vulgare L.). Environmental and Experimental Botany, 53, 29-37. https://doi.org/10.1016/j.envexpbot.2004.02.010

Liu, S., Dong, Y., Xu, L. and Kong, J. (2014). Effects of foliar applications of nitric oxide and salicylic acid on salt-induced changes in photosynthesis and antioxidative metabolism of cotton seedlings. Plant Growth Regulation, 73, 67-78. https://doi.org/10.1007/ s10725-013-9868-6

Ma, D., Sun, D., Wang, C., Qin, H., Ding, H., Li, Y. and Guo, T. (2016). Silicon application alleviates drought stress in wheat through transcriptional regulation of multiple antioxidant defense pathways. Journal of Plant Growth Regulation, 35, 1-10. https://doi.org/10.1007/ s00344-015-9500-2 
Maas E. V. (1986). Salt tolerance in plants. Applications in Plant Sciences, 1, $12-26$.

Madhava Rao, K. V. and Sresty, T. V. S. (2000). Antioxidative parameters in the seedlings of pigeonpea (Cajanus cajan (L.) Millspaugh) in response to Zn and Ni stress. Plant Science, 157, 113-128. https://doi.org/10.1016/s0168-9452(00)00273-9

Miller, G. W., Pushnik, J. C. and Welkie, G. W. (1984). Iron chlorosis a world wide problem, the relation of chlorophyll biosynthesis to iron. Journal of Plant Nutrition, 7, 1-22. https://doi.org/10.1080/01904168409363172

Nakano, Y. and Asada, K. (1981). Hydrogen peroxide is scavenged by ascorbate-specific peroxidase in spinach chloroplasts. Plant and Cell Physiology, 22, 867-880. https://doi.org/10.1093/oxfordjournals.pcp.a076232

Porra, R. J., Thompson, W. A. and Kriedemann, P. E. (1989). Determination of accurate extinction coefficients and simultaneous equations for assaying chlorophyll $a$ and $b$ extracted with four different solvents: verification of the concentration of chlorophyll standards by atomic absorption spectroscopy. Biochimica et Biophysica Acta - Bioenergetics, 975, 384-394. https://doi.org/10.1016/S0005-2728(89)80347-0

Rahbarian, R., Khavari-Nejad, R., Ganjeali, A., Bagheri, A. and Najafi, F. (2011). Drought stress effects on photosynthesis, chlorophyll fluorescence and water relations in tolerant and susceptible chickpea (Cicer arietinum L.) genotypes. Acta Biologica Cracoviensia Series Botanica, 53, 47-56. https://doi.org/10.2478/v10182-011-0007-2

Romero-Aranda, M.R., Jurado, O. and Cuartero, J. (2006). Silicon alleviates the deleterious salt effect on tomato plant growth by improving plant water status. Journal of Plant Physiology, 163, 847-855. https://doi.org/10.1016/j.jplph.2005.05.010

Sairam, R. K., Deshmukh, P. S. and Shukla, D. S. (1997). Tolerance of drought and temperature stress in relation to increased antioxidant enzyme activity in wheat. Journal of Agronomy and Crop Science, 178, 171-178. https://doi.org/10.1111/j.1439-037X.1997.tb00486.x

Santos, C. V. (2004). Regulation of chlorophyll biosynthesis and degradation by salt stress in sunflower leaves. Scientia Horticulturae, 103, 93-99. https://doi.org/10.1016/j.scienta.2004.04.009

Singleton, V. L. and Rossi, J. R. (1965). Colorimetry of total phenolics with phosphomolybdic-phosphotungstic acid. American Journal of Enology and Viticulture, 16, 144-158.

Tavallali, V., Rahemi, M. and Panahi, B. (2008). Calcium induces salinity tolerance in pistachio rootstocks. Fruits, 63, 5, 285-296. https:// doi.org/10.1051/fruits:2008024

Trenholm, L. E., Datnoff, L. E. and Nagata, R. T. (2004). Influence of silicon on drought and shade tolerance of St. Augustinegrass. HortTechnology, 14, 487-490. https://doi.org/10.21273/HORTTECH.14.4.0487

Tuna, A. L., Kaya, C., Higgs, D., Murillo-Amador, B., Aydemir, S. and Girgin, A. R. (2008). Silicon improves salinity tolerance in wheat plants. Environmental and Experimental Botany, 62, 10-16. https://doi.org/10.1016/j.envexpbot.2007.06.006

Yin, R., Bai, T., Ma, F., Wang, X., Li, Y. and Yue, Z. (2010). Physiological responses and relative tolerance by Chinese apple rootstocks to $\mathrm{NaCl}$ stress. Scientia Horticulturae, 126, 247-252. https://doi.org/10.1016/j.scienta.2010.07.027

Yoon, B. S., Jin, C. J., Un, P. S. and Cho, D.H. (2005). Change in photosynthesis, proline content, and osmotic potential of corn seedling under high-saline condition. Korean Journal of Crop Science, 50, 28-31.

Zhang, W., Yu, X., Li, M., Lang, D., Zhang, X. and Xie, Z. (2018). Silicon promotes growth and root yield of Glycyrrhiza uralensis under salt and drought stresses through enhancing osmotic adjustment and regulating antioxidant metabolism. Crop Protection, $107,1-11$. https://doi.org/10.1016/j.cropro.2018.01.005 